\title{
Genetic characterization of rare Bruconha virus (Bunyavirales:Orthobunyavirus) isolated in Vale do Ribeira (Atlantic Forest biome), Southeastern Brazil
}

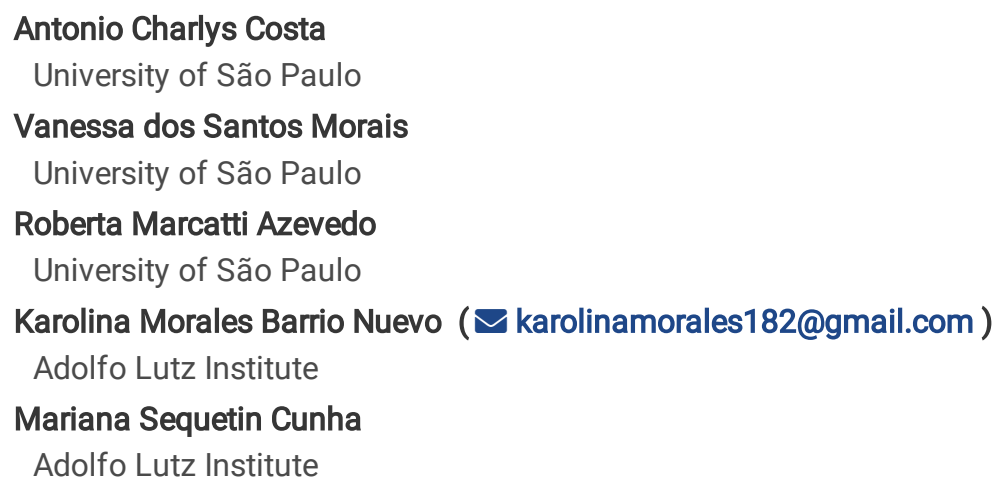

\section{Research Article}

Keywords: Arbovirus, Bunyavirales, Bruconha virus, Active Surveillance, Phylogenetics, Brazil

Posted Date: July 22nd, 2022

DOI: https://doi.org/10.21203/rs.3.rs-1239445/v2

License: @ (1) This work is licensed under a Creative Commons Attribution 4.0 International License. Read Full License 


\section{Abstract}

Brazil is a great source of arbovirus diversity, mainly in the Amazon Region. However, other biomes, especially Atlantic Forest, may be also a hotspot for emergent viruses, including Bunyaviruses (Negarnaviricota: Bunyavirales). For instance, Vale do Ribeira, located in the Southeastern region, has been widely studied for virus surveillance, where Flavivirus, Alphavirus and Bunyaviruses were isolated during the last decades, including Bruconha virus (BRCV), a member of Orthobunyavirus genus Group C, in 1976. Recently, a new isolated of BRCV, named Span321532, was obtained from an adult sentinel mice placed in Iguape county, in 2011, and a full-length genome was generated, with nucleotide differences that varied from 1.5\%, 5.3\% and $5 \%$ (L, M and S segments respectively) from the prototype isolated 35 years earlier. Although no evidence of reassortants were detected, this findings reiterates the need for new surveillance and genomic studies in the area considering the high mutation rates of arbovirus and also to identify the hosts capable of supporting the continuous circulation of Orthobunyavirus.

\section{Introduction}

Central and South America are a great source of arbovirus diversity, and hotspots of emergent zoonoses [1]. In Brazil, outbreaks of Flavivirus and Alphavirus, such as Dengue, Chikungunya, Yellow Fever and Zika are described all over the country [2-4]. On the other hand, despite its lower incidence, Bunyaviruses (Negarnaviricota: Bunyavirales) are a large and diverse group of viruses that are important pathogens. Their genome is segmented and composed of three segments: a large $(L)$ segment encoding a protein that functions as an RNA-directed RNA polymerase (RdRp); a medium (M) segment encoding glycoproteins ( $\mathrm{G}$ and Gc); and a small (S) segment encoding a nucleoprotein (NP) and, in some clades, a non-structural protein, NSs, with a RNA of negative-sense. Within the order, Orthobunyavirus genus, belonging to the Peribunyaviridae family, contains 103 species divided into distinct serogroups [5, 6], of which several can have impact in humans and animals health, such as Oropouche virus and Schmallenberg virus.

Several orthobunyaviruses, mainly from groups $\mathrm{C}$ and Guama, have been isolated at Atlantic Forest biome within São Paulo State (southeastern Brazil) during active surveillance programs for arbovirus during the 60's and 70's, such as Bertioga virus (BERV), Boraceia virus (BORV), Cananeia virus (CNAV), Caraparu virus (CARV), Guaratuba virus (GTRV) and Itimirim virus (ITIV) (4-7). In the Atlantic Forest, it is believed that these viruses are maintained mainly by rodents (or other small mammals) and Culex mosquitoes [10]. As described for segmented genomes, orthobunyaviruses are capable of reassortment, which can have epidemiological importance [11]. For instance, Ngari virus is a reassortant bunyavirus associated with outbreaks of hemorrhagic fever in Africa [12]; Iquitos and Itaya viruses are emerging reassortant bunyaviruses associated with human illness in Peru [13]. Reassortants are also described in Group C Orthobunyaviruses, once phylogenetic analysis revealed that Caraparu virus, that circulates in Brazil, contained an S segment sequence that is nearly identical to Oriboca virus, indicating a natural reassortant virus [14]. However, as viruses belonging to Peribunyaviridae family are rarely found in the Southeastern region of Brazil, where Oropouche virus has never been detected, little is known about the epidemiological cycle and virus evolution at this particular biome. Here we describe a full length genome of Bruconha virus (BRCV), a group C Orthobunyavirus isolated in 2011, in Iguape city, São Paulo, Brazil.

\section{Methods}

\subsection{Area}

In São Paulo State, during the arbovirus eco-epidemiology surveillance program, mosquitoes and blood samples from birds. Also, sentinel mice were placed in selected areas with water and food ad libitum. This program was conducted from 2011 until 2016 at Vale do Ribeira, an Atlantic Florest region located at the south coast of the State (Fig. 1). The aim of this project was to identify arbovirus hosts and vectors, and also the circulation of these viruses in human and animal populations. Vale do Ribeira region is occupied by the hydrographic basin of the Ribeira do Iguape river, and includes 16 counties. It has over $21,000 \mathrm{Km}^{2}$ of well-preserved forests (about $21 \%$ of the total remaining Atlantic Forest in Brazil). The region has high temperatures with high rainfall during the year as depicted in Fig. 2. Economy is based on subsistence agriculture. Besides the biological diversity of Vale do Ribeira, this region was selected thanks to previous detection of several arbovirus, including the outbreak caused by the flavivirus Rocio virus (1975-1977)[9]. It is known that deforestation has increased in Brazil during the last years, mainly in the Amazon region [15]. In order to check the conservation at Vale do Ribeira, we have used mapbiomas plug in in QGIS v 3.16 (https://mapbiomas.org/), comparing Atlantic Forest biome in 1986 and 2011, showing the forest maintenance during the last 3 decades (Supplementary material).

\subsection{Sample Collection}


In 2011, a total of 6 field trips of 3-day long, being 5 to Iguape city and one to Panorama (months of March, April, May and November) were conducted. Nets were used for the capture of wild birds, while domestic birds were hold by the owner. Also, each trip had two sentinel Swiss mice cages with 1 mother and 6 newborns each (total $=12)$, with water and food ad libitum [16]. Blood samples from birds $(0.2-$ $0.3 \mathrm{ml}$ ) were collected by venipuncture and diluted in a phosphate-buffered saline solution with $0.75 \%$ bovine albumin, penicillin (100 units $/ \mathrm{mL})$ and streptomycin $(100 \mu \mathrm{g} / \mathrm{mL})$. All free range animals were released. Sentinel mice were brought back to the laboratory and observed for 21 days. Table 1 shows all bird captures performed during 2011.

Table 1

Species of birds captured during arbovirus surveillance program in Iguape city, SP, Brazil, 2011

\begin{tabular}{|lll|}
\hline Family & Specie & Number of individuals \\
\hline Anatidae & Anas platyrhynchos domesticus & 23 \\
\hline Psittacidae & Brotogeris tirica & 1 \\
\hline Coerebidae & Coereba flaveola & 2 \\
\hline Columbidae & Columbina talpacoti & 1 \\
\hline Conopophagidae & Conopophaga lineata & 1 \\
\hline Tyrannidae & Fluvicola nengeta & 1 \\
\hline Funariidae & Furnarius rufus & 4 \\
\hline Tyrannidae & Leptopogon amaurocephalus & 1 \\
\hline Pipridae & Manacus manacus & 2 \\
\hline Tyrannidae & Myiophobus fasciatus & 1 \\
\hline Tyrannidae & Myozetetes similis & 1 \\
\hline Hirundinidae & Notiochelidon cyanoleuca & 2 \\
\hline Picidae & Picumnus temminckii & 1 \\
\hline Thraupidae & Ramphocelus bresilius & 3 \\
\hline Trochilidae & Ramphodon naevius & 1 \\
\hline Thraupidae & Saltator similis & 3 \\
\hline Thraupidae & Sicalis flaveola & 4 \\
\hline Fringillidae & Sporophila caerulescens & 14 \\
\hline Hirundinidae & Stelgidopteryx ruficollis & 8 \\
\hline Thraupidae & Tangara seledon & 3 \\
\hline Thraupidae & Thraupis sayaca & 1 \\
\hline Troglodytidae & Troglodytes aedon & 3 \\
\hline Turdidae & Turdus amaurochalinus & 1 \\
\hline Turdidae & Turdus rufiventris & 1 \\
\hline Fringillidae & Zonotrichia capensis & 1 \\
\hline
\end{tabular}

\subsection{Virus isolation and Indirect immune assay (IFA)}

Blood samples from birds were inoculated intracerebrally into newborn mice, and checked daily. Tissues (spleen, liver and brain) from the sentinel mice that died within 21 days or showed symptoms of viral infection (paralysis, ataxia) were triturated in sterile grinders containing $1 \mathrm{~mL}$ of phosphate-buffered saline solution with $0.75 \%$ bovine albumin, penicillin $(100 \mathrm{units} / \mathrm{mL})$ and streptomycin $(100$ $\mu \mathrm{g} / \mathrm{mL}$ ). The resultant suspension was centrifuged at $1800 \times \mathrm{g}$ for $15 \mathrm{~min}$. The supernatant was withdrawn and frozen at $-70^{\circ} \mathrm{C}$ until further processing. Each fragment was inoculated into cell tubes containing monolayer cultures of $\mathrm{C} 6 / 36$ cells. Culture tubes were incubated for nine days at $28^{\circ} \mathrm{C}$ with L-15 medium containing $2 \% \mathrm{FBS}$, penicillin (100units $/ \mathrm{mL}$ ) and streptomycin $(100 \mu \mathrm{g} / \mathrm{mL})$. Indirect

Page $3 / 10$ 
immune assay (IFA) tests were then performed using a in house hyper immune serum for detection of genus Flavivirus (antibody antiSaint Louis virus), Alphavirus (antibody anti-Mayaro virus) and Bunyavirus (antibody anti-Caraparu virus) [17].

\subsection{Sequencing}

RNA was extracted from isolate Span321532 C6/36 supernatant using QIAamp Viral RNA Mini Kit following the manufacturer's instructions (QIAGEN, Hilden, Germany).

The protocol used to perform deep sequencing was a combination of several protocols normally applied to viral metagenomics and/or virus discovery (24). In summary, $50 \mathrm{mg}$ of each triturated brain supernatant was diluted in $500 \mu \mathrm{L}$ of Hanks' buffered salt solution (HBSS), added to a $2 \mathrm{~mL}$ impact-resistant tube containing lysing matrix C (MP Biomedicals, USA), and homogenized in a FastPrep-24 5G Homogenizer (MP biomedicals, USA). The homogenized sample was centrifuged at 12,000×g for $10 \mathrm{~min}$, and approximately $300 \mu \mathrm{L}$ of the supernatant was then percolated through a $0.45 \mu \mathrm{m}$ filter (Merck Millipore, Billerica, MA, USA) to remove eukaryotic and bacterial cell-sized particles. One hundred microliters of cold PEG-it Virus Precipitation Solution (System Biosciences, CA, USA), roughly equivalent to onefourth of the volume of the tube, was added to the filtrate, the contents of the tubes were gently mixed and then incubated at $4^{\circ} \mathrm{C}$ for $24 \mathrm{~h}$. The mixture was subsequently centrifuged at $10,000 \times \mathrm{g}$ for $30 \mathrm{~min}$ at $4^{\circ} \mathrm{C}$ and the supernatant $(\sim 350 \mu \mathrm{L})$ was discarded. The viral particlerich pellet was treated with a mixture of nuclease enzymes (14 uni TURBO Dnase and 7 uni RNase Cocktail Enzyme Mix-Thermo Fischer Scientific, CA, USA; 9 uni Baseline-ZERO DNase - Epicentre, WI, USA; 25 Benzonase - Darmstadt, Germany; and 9 RQ1 RNase- Free DNase and $0.09 \mathrm{mg}$ RNase A Solution - Promega, WI, USA) to digest unprotected nucleic acids. The resulting mixture was subsequently incubated at $37^{\circ} \mathrm{C}$ for $2 \mathrm{~h}[18]$.

After incubation, viral nucleic acids were extracted using the ZR \& ZR-96 Viral DNA/RNA Kit (Zymo Research, CA, USA) according to the manufacturer's protocol. The cDNA synthesis was performed using AMV reverse transcriptase (Promega, WI, USA). A second strand of cDNA was synthetized using DNA Polymerase I Lar e (Klenow) Fragment (Promega, WI, USA). Subsequently, a Nextera XT Sample Preparation Kit (Illumina, CA, USA) was used to construct a DNA library, identified using dual barcodes. For size range, Pippin Prep (Sage Science, Inc.) was used to select a 300 bp insert (range 200-400 bp). The library was deep-sequenced using the HiSeq 2500 Sequencer (Illumina, CA, USA) with 126 bp ends [19]. Following de novo assembly of short sequence reads longer contigs were made using the customized de novo assembly software previously described [20]. Viral sequences were recognized by translating them in silico in all six possible reading frames. These virtual protein sequences were then used for similarity searches using BLASTx against the proteins of all viral genomes in GenBank. The bioinformatics pipeline trimed sequences of primers involved in the random RT-PCR reaction and kept only a single copy of repeated sequences. Residual sequences from the human genome were also removed to accelerate analyses. Contigs of overlapping short reads were then generated using an in-house hybrid de novo assembler program specially designed for viral metagenomics, generating longer contigs to facilitate the recognition of highly divergent viral genomes $[19,20]$. A search was then performed for sequence similarity against all annotated viral genomes in GenBank. We used a protein computationally demanding step to reduce signal noise by removing from the list of tentative viral hits those sequences with higher levels of similarity to non-viral sequences (based on annotation) in the large NR (nonredundant) GenBank database. This NR database shows the family/genus/species of viruses with similarity to the generated data set (with adjustable E score ranges). The pipeline was fast and sensitive, allowing even highly divergent viruses with only 15-20\% protein identity (depending on length of contigs) to be recognized [19]. The final genome analysis was performed using Geneious software v9.1.8 (Biomatters Ltd., Auckland, New Zealand). Open reading frames were predicted with the Geneious ORF finder. Based on the bioinformatics pipeline used [19], no reads related to human, fungal, or bacterial sequences were obtained.

\subsection{Aligment and Phylogenetic Analysis}

Sequences from segments $S, M$ and L ORFs were aligned with different groups of Orthobunyavirus on amino acid sequences using the Muscle algorithm and manually inspected using Mega v.7 [21]. For segment S, only the nucleoprotein ORF (NP) was aligned. After alignment, sequences were then converted back to their original nucleotide sequences for phylogenetic analysis. Sequences with excessive gaps in the alignment were removed. Rio Preto da Eva virus (Pacuvirus) was used as the outergroup. The best model and phylogenetic analysis were performed using IQ- TREE with a ultrafast bootstrap (1000 replicates) [22, 23], and the tree generated was edited using FigTree v.14.3 with a mid-point root. Similarities between the segments and other Orthobunyavirus were calculated using BioEdit Sequence Alignment Editor [24]. Nucleotide sequences for segments S, M and L determined in this study have been deposited in GenBank under accession numbers OK338018-0K338020.

\section{Results}


Samples of liver and spleen obtained from an adult sentinel mice (named Span321532) placed on May 25th 2011 in Iguape city (24 $38^{\prime}$ $412^{\prime \prime}$ S, $47^{\circ} 29^{\prime} 214 \mathrm{~W}$ ) ( ure 2)that was euthanized was positive for anti-Caraparu virus hyperimune sera after one passage in C6/36 cell lines. Brain sample was negative, suggesting that BRCV is not neurotropic. No virus was isolated from birds. For phylogenetic analysis, for segment $S$ the best model according to $B I C$ was $T V M+F+I+G 4$; for $M$ and $L$ segments, $G T R+F+I+G 4$ were used. All trees placed SPAN321532 within Group C of Orthobunyavirus with high bootstrap values, in close proximity with BRCV prototype strain from 1976 (GenBank accession numbers MK896603-MK896605) (Fig. 3A-C), with similarities of $98.5 \%$ for L segment, $94.7 \%$ for M and $95 \%$ for S (Table 2). No reassortant events were detected for this new isolate. However, each segment placed BRCV Span321532 within different clusters. For segment S (NP), BRCV clustered with all Caraparu virus strains, Madrid virus, Vinces virus and Itaqui virus; for M segment, with Caraparu strains, Apeu virus, Vinces virus and Madrid virus, and for L segment, with Caraparu strains, Oriboca virus, Itaqui virus, Madrid virus and Vinces virus, which were similar to those previously detected [5]. Similarities within members of Orthobunyavirus Group $\mathrm{C}$ are depicted in Table 2.

Table 2

S, M and L segments similarities (\%) between Bruconha virus Span321532 and Group C orthobunyavirus

\begin{tabular}{|c|c|c|c|c|c|c|c|c|c|c|c|c|c|c|c|}
\hline $\begin{array}{l}\text { Span } \\
32153\end{array}$ & BRCV & ITQV & MURV & GLV & ORIV & $\begin{array}{l}\text { CARV } \\
\text { Bean3994 }\end{array}$ & $\begin{array}{l}\text { CARV } \\
\text { FMD0783 }\end{array}$ & $\begin{array}{l}\text { CARV } \\
\text { IQD5973 }\end{array}$ & $\begin{array}{l}\text { CARV } \\
\text { FVB0426 }\end{array}$ & RESV & MADV & MTBV & VINV & APEUV & NEPV \\
\hline $\mathrm{s}$ & 95 & 082.9 & 68.7 & 69.7 & 69.3 & 82.5 & 82.2 & 81.5 & 81.7 & 69.5 & 81.7 & 69.7 & 80.8 & 70.7 & 68.3 \\
\hline M & 94.7 & 62 & 68.6 & 67.2 & 63.5 & 72.4 & 72.5 & 72.7 & 73.1 & 67.4 & 71 & 68.4 & 71.2 & 71.6 & 67 \\
\hline L & 98.5 & 77.2 & 73 & 71.9 & 77 & 77 & 78.1 & 77.9 & 77.6 & 73 & 77.6 & 73.4 & 77.3 & 72.5 & 72 \\
\hline
\end{tabular}

\section{Discussion}

Here we describe a new coding-complete genome of a rare Bruconha orthobunyavirus, isolated in 2011 at Brazilian Atlantic Forest biome. In 1961, Adolfo Lutz Institute started a program that aimed to investigate arbovirus epidemiology and diversity in São Paulo State, when several arboviruses, including new Bunyavirales, were discovered and characterized. For instance, Boraceia virus, a member of the Anopheles B group, was isolated from a pool of Anopheles cruzii at Serra do Mar, a forest area near São Paulo city, in 1962 [7], and later from Phoniomyia pilicauda [25]. This virus was considered the causative agent of an infectious illness among residents in Salesópolis, distant $100 \mathrm{Km}$ away from São Paulo city, the capital of the State [25]. Strains of Bertioga virus (Guama group) and Anhembi virus (Bunyamera group) were isolated from sentinel mice, Phoniomyia pilicauda, Trichoprosopon pailidiventer, and from a spiny rat (Proechimys iheringi) [10]. BRCV was isolated from Culex sacchettae mosquitoes in Iguape city, on February, April and November, 1976. Almost 4 decades later, we describe a new isolate of BRCV from the same county, showing viral maintenance within its hosts. We also found that nucleotide identity diverged 1.5\%, 5.3\% and 5\% (L, M and S segments respectively) from the 1976 prototype. Unfortunately, coordinates from this strain are not available.

Reassortant events have shaped the evolution of several segmented viruses, including Group C orthobunyaviruses [5, 11], and it was proposed that BRCV obtained its S segment from CARV [14]. On the other hand, Caraparu and Itaqui viruses had nearly identical L and S segments, but different M segments. Interestingly, within group C, Span321532 had the highest S segment ( $N$ protein) similarity with Itaqui virus (82.9\%), while M and L segments with different Caraparu strains: one isolated in Bolivia in 2008, and the other in Peru, in 2006, respectively. It is important to note that Caraparu isolates were obtained from the Brazilian Amazon basin, at the Northern region, Peru, and also in São Paulo state, from Culex mosquitoes, humans and non-human primates [14]. However, BRCV was never isolated outside Atlantic Forest, although intensive programs for virus discovery have been performed during the last decades in Brazil. These differences corroborates with previous studies which demonstrates that the $S$ and $M$ segments have different evolutionary histories [14]. However, isolate Span321532 had no evidence of reassortants within other Orthobunyavirus belonging to group C.

Only one human case that was caused by Caraparus virus (or a close-related virus) was described at Vale do Ribeira: a 28 year old male biologist that worked with entomological investigation presented a mild febrile disease, who fully recovered [8]. As this virus is quite similar to BRCV, it is likely that BRCV may cause an undiagnosed illness at the region. Interestingly, despite arbovirus high mutation rates and the great diversity of pathogenic orthobunyavirus at Vale do Ribeira, outbreaks were never reported in the southeastern region of 
Brazil. In fact, the circulation of several arbovirus are often related with climate, habitat, presence of vectors and animal density and movement. A possible explanation regarding the low disease incidence at Vale do Ribeira is the conservation of the biome, where a dilution effect may occur [27]. This region harbors several conservation units since the 1980's, with lower deforestation of Atlantic Forest remnants when compared to other Brazilian biomes, which may decrease the risk of human infection. More, BRCV apparently is restricted to Atlantic Forest biome, where only two genomes were obtained until now within a 35 years interval, with high similarities and lack of reassortant events. Increasing virus active surveillance in order to obtain more sequences of Bunyavirales would generate improvements on information regarding viral genetics and evolution, shedding light in this question. More, given the high biodiversity in Vale do Ribeira, these studies would allow us to better known sylvatic hosts and vectors. Although it is known that Group C Orthobunyavirus circulate among rodents, marsupials and eventually humans in São Paulo State, epidemiological aspects regarding BRCV are scarce. More, in order to understand the patterns of other arbovirus circulation in the human population at Vale do Ribeira, it is urged to perform differential diagnosis for Dengue, Zika and Chikungunya viruses during the acute phase, when methods for viral detection can be performed.

\section{Declarations}

\section{Acknowledgements}

We thank the staff of the Vector-Borne Diseases Laboratory of Adolfo Lutz Institute Iray Maria Rocco and Teresinha Lisieux Moraes Coimbra for performing viral isolation and IFA tests, and Jeferson Aparecido de Souza and Luis Eloy Pereira (in memorian) for sample collection and bird identification.

Ethics: this research was approved by CEUA under the protocol 02/2011 "Programa de vigilância ecoepidemiológica de arbovirus no estado de São Paulo", by Dr. Luis Eloy Pereira. Laboratory animals used herein were euthanized using $\mathrm{CO}^{2}$ chamber

Author Contributions: Manuscript preparation: MSC, ACC. Obtained funding and study supervision: MSC. Experiments of viral detection and NGS: ACC, VSM, RM. Performed the analyses: MSC, KMBN. All authors reviewed, contributed to, and approved the final version of the manuscript.

Funding: Secretaria de Estado da Saúde (SES) de São Paulo, GAPS Fesima CAF n. ${ }^{0}:$ 076/2019. Also, KMBN was supported by FEDIAL scholarship (Programa de Formação para Investigação Científica) at Adolfo Lutz Institute.

Competing Interests: The authors have no relevant financial or non-financial interests to disclose.

\section{References}

1. Olival KJ, Hosseini PR, Zambrana-Torrelio C, et al (2017) Host and viral traits predict zoonotic spillover from mammals. Nature 546:646-650. https://doi.org/10.1038/nature22975

2. Nunes MRT, Faria NR, de Vasconcelos JM, et al (2015) Emergence and potential for spread of Chikungunya virus in Brazil. BMC Med 13:102. https://doi.org/10.1186/s12916-015-0348-x

3. Faria NR, Kraemer MUG, Hill SC, et al (2018) Genomic and epidemiological monitoring of yellow fever virus transmission potential. Science 361:894-899. https://doi.org/10.1126/science.aat7115

4. Faria NR, Azevedo S, Kraemer MUG, et al (2016) Zika virus in the Americas: Early epidemiological and genetic findings. 352 :

5. Kapuscinski ML, Bergren NA, Russell BJ, et al (2021) Genomic characterization of 99 viruses from the bunyavirus families Nairoviridae, Peribunyaviridae, and Phenuiviridae, including 35 previously unsequenced viruses. PLoS Pathog 17:e1009315. https://doi.org/10.1371/journal.ppat.1009315

6. Walker PJ, Siddell SG, Lefkowitz EJ, et al (2020) Changes to virus taxonomy and the Statutes ratified by the International Committee on Taxonomy of Viruses (2020). Arch. Virol. 165:2737-2748

7. Lopes $O$ de S, Forattini OP, Fonseca IE, et al (1966) Boracéia virus. A new virus related to anopheles B virus. Proc Soc Exp Biol Med Soc Exp Biol Med (New York, NY) 123:502-504. https://doi.org/10.3181/00379727-123-31526

8. Iversson LB, Travassos da Rosa AP, Coimbra TL, et al (1987) Human disease in Ribeira Valley, Brazil caused by Caraparu, a group C arbovirus-report of a case. Rev Inst Med Trop Sao Paulo 29:112-117. https://doi.org/10.1590/s0036-46651987000200009

9. LOPES ODES, COIMBRA TLM, SACCHETTA LIADEA, CALISHER CH (1978) EMERGENCE OF A NEW ARBOVIRUS DISEASE IN BRAZIL: I. ISOLATION AND CHARACTERIZATION OF THE ETIOLOGIC AGENT, ROCIO VIRUS. Am J Epidemiol 107:444-449.

https://doi.org/10.1093/oxfordjournals.aje.a112563

Page 6/10 
10. Calisher $\mathrm{CH}$, Coimbra TL, Lopez $\mathrm{O}$ de S, et al (1983) Identification of new Guama and Group $\mathrm{C}$ serogroup bunyaviruses and an ungrouped virus from Southern Brazil. Am J Trop Med Hyg 32:424-431. https://doi.org/10.4269/ajtmh.1983.32.424

11. Briese T, Calisher $\mathrm{CH}$, Higgs S (2013) Viruses of the family Bunyaviridae: are all available isolates reassortants? Virology 446:207216. https://doi.org/10.1016/j.virol.2013.07.030

12. Gerrard SR, Li L, Barrett AD, Nichol ST (2004) Ngari virus is a Bunyamwera virus reassortant that can be associated with large outbreaks of hemorrhagic fever in Africa. J Virol 78:8922-8926. https://doi.org/10.1128/JVI.78.16.8922-8926.2004

13. Aguilar P V, Barrett AD, Saeed MF, et al (2011) Iquitos virus: a novel reassortant Orthobunyavirus associated with human illness in Peru. PLoS Negl Trop Dis 5:e1315. https://doi.org/10.1371/journal.pntd.0001315

14. Nunes MRT, Travassos da Rosa APA, Weaver SC, et al (2005) Molecular epidemiology of group C viruses (Bunyaviridae, Orthobunyavirus) isolated in the Americas. J Virol 79:10561-10570. https://doi.org/10.1128/JVI.79.16.10561-10570.2005

15. Silva Junior CHL, Pessôa ACM, Carvalho NS, et al (2021) The Brazilian Amazon deforestation rate in 2020 is the greatest of the decade. Nat Ecol Evol 5:144-145. https://doi.org/10.1038/s41559-020-01368-x

16. CAUSEY OR, CAUSEY CE, MAROJA OM, MACEDO DG (1961) The isolation of arthropod-borne viruses, including members of two hitherto undescribed serological groups, in the Amazon region of Brazil. Am J Trop Med Hyg 10:227-249

17. Gubler DJ, Kuno G, Sather GE, et al (1984) Mosquito cell cultures and specific monoclonal antibodies in surveillance for dengue viruses. Am J Trop Med Hyg 33:158-165

18. Charlys da Costa A, Theze J, Komninakis SCV, et al (2017) Spread of Chikungunya Virus East/Central/South African Genotype in Northeast Brazil. Emerg Infect Dis 23:1742-1744. https://doi.org/10.3201/eid2310.170307

19. Deng X, Naccache SN, Ng T, et al (2015) An ensemble strategy that significantly improves de novo assembly of microbial genomes from metagenomic next-generation sequencing data. Nucleic Acids Res 43:e46. https://doi.org/10.1093/nar/gkv002

20. Wommack KE, Bhavsar J, Ravel J (2008) Metagenomics: read length matters. Appl Environ Microbiol 74:1453-1463. https://doi.org/10.1128/AEM.02181-07

21. Kumar S, Stecher G, Tamura K (2016) MEGA7: Molecular Evolutionary Genetics Analysis Version 7.0 for Bigger Datasets. Mol Biol Evol 33:1870-1874. https://doi.org/10.1093/molbev/msw054

22. Nguyen L-T, Schmidt HA, von Haeseler A, Minh BQ (2015) IQ-TREE: a fast and effective stochastic algorithm for estimating maximumlikelihood phylogenies. Mol Biol Evol 32:268-274. https://doi.org/10.1093/molbev/msu300

23. Minh BQ, Nguyen MAT, von Haeseler A (2013) Ultrafast approximation for phylogenetic bootstrap. Mol Biol Evol 30:1188-1195. https://doi.org/10.1093/molbev/mst024

24. Hall TA (1999) BioEdit: a user-friendly biological sequence alignment editor and analysis program for Windows $95 / 98 / N T$. Nucleic Acids Symp. Ser. 41:95-98

25. de Souza Lopes O, de Abreu Sacchetta L (1974) Epidemiology of Boraceia virus in a forested area in São Paulo, Brazil. Am J Epidemiol 100:410-413. https://doi.org/10.1093/oxfordjournals.aje.a112052

26. Askar W, Menaria P, Thohan V, Brummitt CF (2020) Jamestown Canyon virus encephalitis in a heart transplant patient. Transpl. Infect. Dis. 22:e13210

27. Khalil H, Ecke F, Evander M, et al (2016) Declining ecosystem health and the dilution effect. Sci Rep 6:31314. https://doi.org/10.1038/srep31314

\section{Figures}




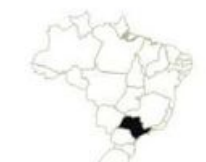

A

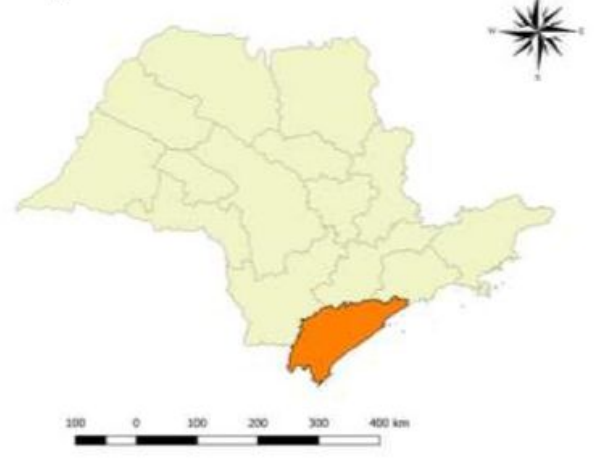

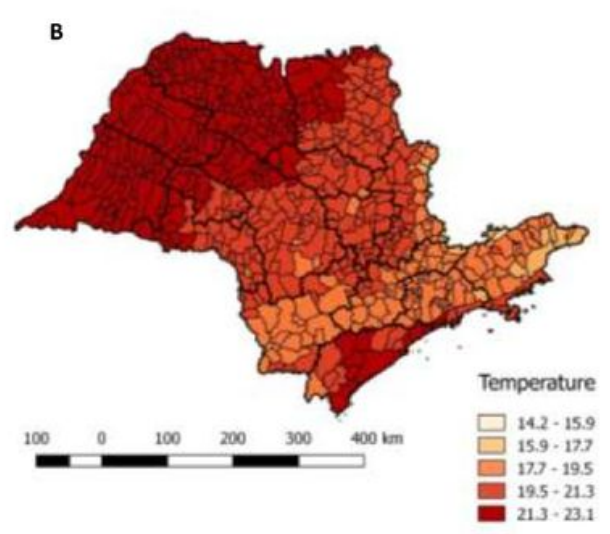

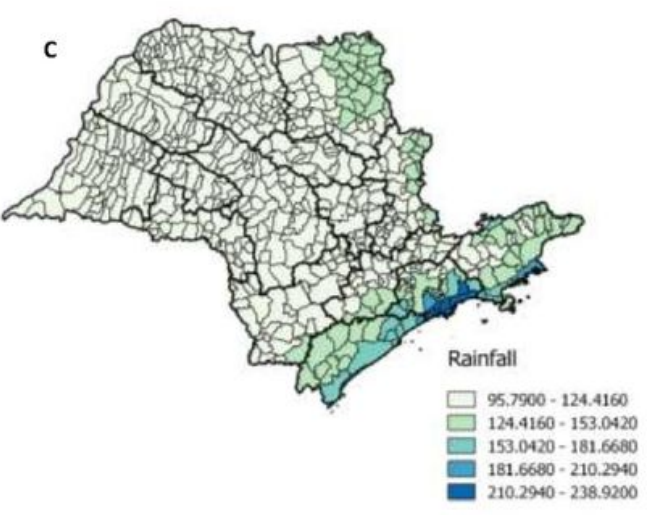

\section{Figure 1}

São Paulo State map showing the location of Vale do Ribeira (in orange)(A), average temperature (B) and rainfall (C) 


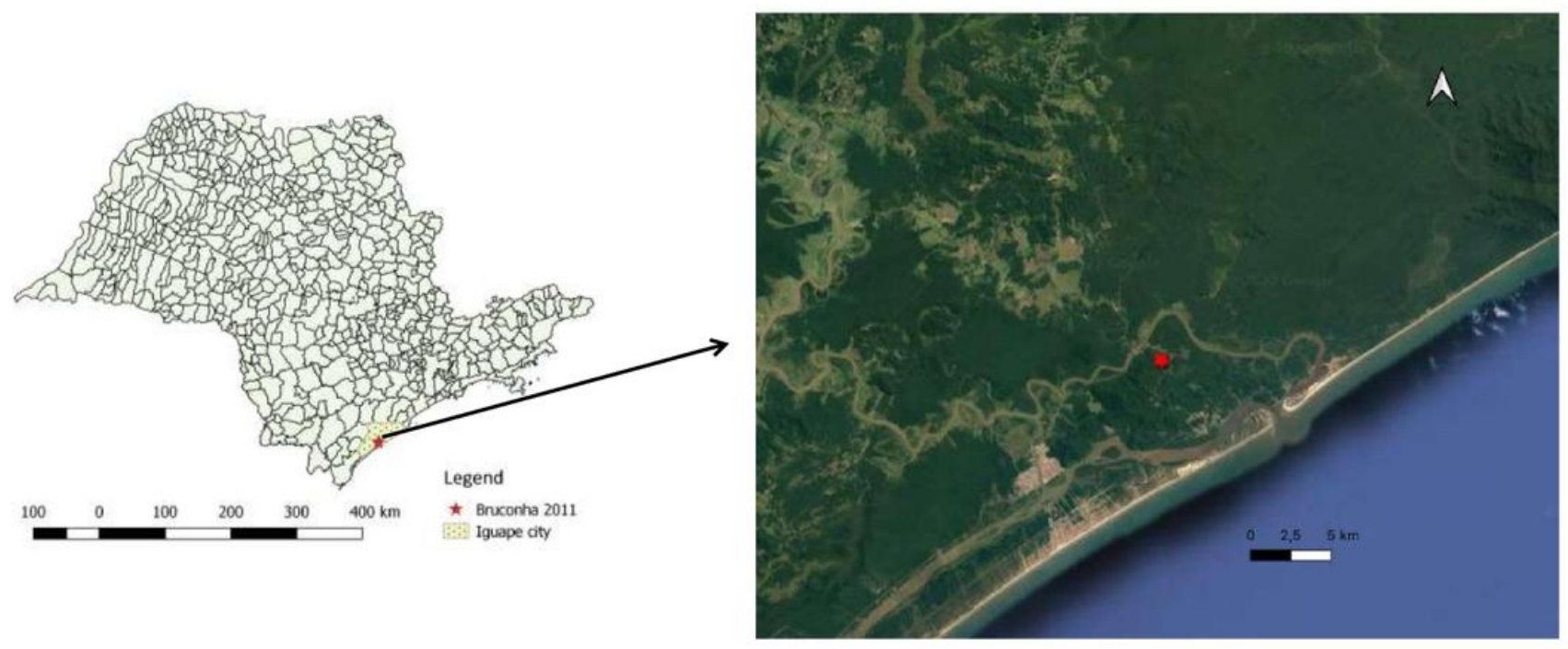

\section{Figure 2}

São Paulo State map showing Iguape city and the location of BRCV 2011 Span321532 strain isolation. 

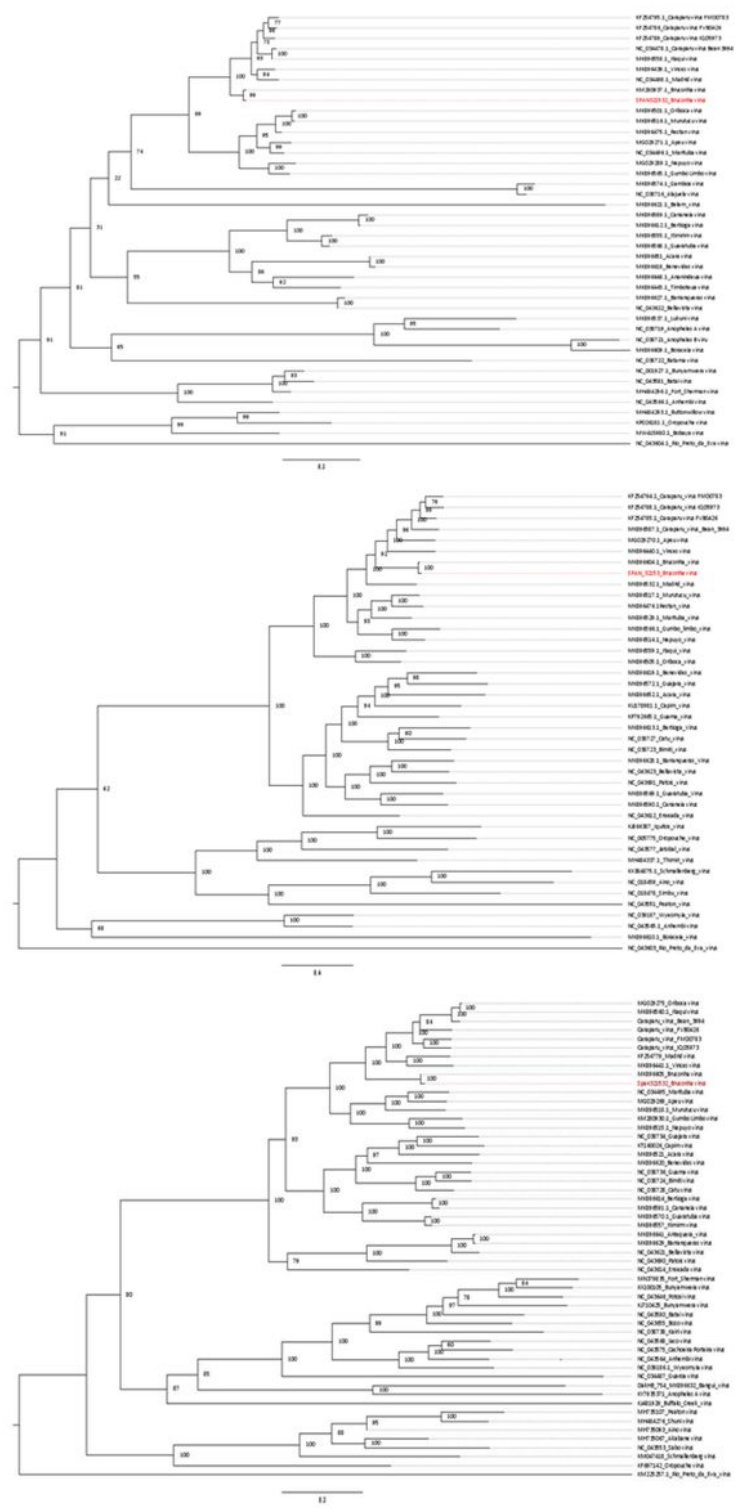

Figure 3

Phylogenetic tree of the BRCV isolate Span321532. Sequences of Orthobunyavirus ORFs whole genomes were aligned using MUSCLE codon in MEGA 7 software [21]. Best model for each segment and the maximum likelihood tree were obtained and constructed using IQTree [22]. (A) Phylogenetic tree of S segment. (B) Phylogenetic tree of $M$ segment. (C) Phylogenetic tree of $L$ segment. BRCV is depicted in red. Tree was constructed using FigTree v.1.4.3 with an automatic scale and mid-point root. Scale in nucleotide substitutions per site. Numbers at nodes indicate bootstrap values. Rio Preto da Eva virus was used as outergroup.

\section{Supplementary Files}

This is a list of supplementary files associated with this preprint. Click to download.

- Supplementarymaterial.docx 